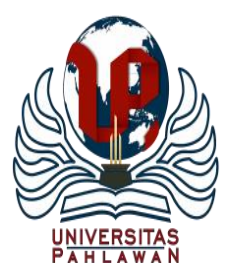

Edukatif : Jurnal Ilmu Pendidikan Volume 3 Nomor 3 Tahun 2021 Halm 777 - 784 EDUKATIF: JURNAL ILMU PENDIDIKAN

Research \& Learning in Education

https://edukatif.org/index.php/edukatif/index

\title{
Kontribusi Profesionalisme Guru Kelas dan Minat Baca Siswa dalam Meningkatkan Prestasi Hasil Pembelajaran Tematik Integratif
}

\author{
Ahmad Sholeh \\ UIN Maulana Malik Ibrahim Malang \\ E-mail : Sholeh76@yahoo.com
}

\begin{abstract}
Abstrak
Guru kelas yang profesional masih belum terealisasi secara merata di seluruh lembaga pendidikan dasar yang ada. Di sisi lain, kita juga menyaksikan minat baca siswa di Indonesia sangatlah rendah. Penelitian ini bertujuan untuk mengetahui seberapa besar kontribusi profesionalisme guru kelas dan minat baca siswa dalam meningkatkan prestasi hasil pembelajaran tematik integratif. Penelitian ini menggunakan jenis penelitian survei yang bersifat Ex Post Facto di MI Raden Fatah Pujon. Adapun teknik analisis datanya menggunakan teknik analisis statistic inferensial dengan menggunakan analisis regresi ganda. Hasil penelitian ini menyatakan bahwa prestasi hasil belajar pembelajaran tematik integratif dipengaruhi oleh kopetensi profesioanal guru kelas dan minat baca siswa secara bersama-sama dengan kontribusi $36,7 \%$. Ini berarti prestasi hasil belajar pembelajaran tematik integratif selebihnya dipengaruhi oleh variabel lainnya Dengan mempertimbangkan hasil penelitian ini maka perbaikan profesionalisme guru kelas dan minat baca siswa dalam rangka meningkatkan kualitas mutu pembelajaran tematik integratif di Madrasah Ibtidaiyah harus terus dilakukan.
\end{abstract}

Kata kunci: Profesionalisme, Minat Baca dan Hasil belajar.

\begin{abstract}
Professional homeroom teachers are still not evenly realized in all existing primary education institutions. On the other hand, we also see that the students' reading interest in Indonesia very low. This study aims to determine how much the contribution of homeroom teacher professionalism and students' reading interest in improving integrative thematic learning outcomes. This study uses a type of survey research that is Ex Post Facto at MI Raden Fatah Pujon. The data analysis technique uses inferential statistical analysis techniques using multiple regression analysis. The results of this study indicate that integrative thematic learning outcomes is influenced by the professional competence of homeroom teachers and students' reading interest, together with a contribution of 36.7\%. This means that other variables influence the remaining integrative thematic learning outcomes. By considering the results of this study, the improvement of the professionalism of homeroom teachers and students' reading interest to improve the quality of integrative thematic learning at Madrasah Ibtidaiyah must be continued.
\end{abstract}

Keywords: Professionalism, Reading Interest and Learning outcomes.

Copyright (c) 2021 Ahmad Sholeh

$\triangle$ Corresponding author

Email : Sholeh 76@yahoo.com

DOI : https://doi.org/10.31004/edukatif.v3i3.425

ISSN 2656-8063 (Media Cetak)

ISSN 2656-8071 (Media Online)

Edukatif : Jurnal Ilmu Pendidikan Vol 3 No 3 Tahun 2021

p-ISSN 2656-8063 e-ISSN 2656-8071 
778 Kontribusi Profesionalisme Guru Kelas dan Minat Baca Siswa dalam Meningkatkan Prestasi Hasil Pembelajaran Tematik Integratif-Ahmad Sholeh

DOI: https://doi.org/10.31004/edukatif.v3i3.425

\section{PENDAHULUAN}

Menurut Gaffar bahwasanya seorang guru mempunyai peranan yang sangat strategis dalam mengembangkan kepribadian para siswa dalam rangka membentuk watak suatu bangsa dengan nilai-nilai karakter yang baik. Peran inilah yang tidak bisa digantikan oleh orang lain walaupun dengan teknologi yang canggih (Sukmawati, 2016). Oleh karena itulah sebagai seorang guru haruslah profesional dalam mendidik atau mengajar kepada siswanya agar dapat mentransfer ilmu pengetahuan dan mentransfer nilai secara berkelanjutan Selanjutnya Kristiawan menyatakan seorang guru professional dalam proses pembelajaran akan memiliki kompetensi professional dan wawasan yang sangat luas dalam menunjang tugas-tugasnya sebagai pendidik. Guru professional akan menampilkan sikap berbeda di depan para siswanya dibanding dengan yang tidak professional. Guru professional semacam ini akan selalu meningkatkan dan mengembangkan kualitas kompetensinya. (Rosmawati et al., 2020).

Guru professional akan selalu belajar sepanjang hayat untuk meningkatkan kompetensinya. Sebenarnya sudah banyak cara yang digunakan untuk mengembangkan keprofesionalan seorang guru, di antaranya dengan pelatihan lesson study. Hal ini seperti pendapatnya Lamb (Hayu et al., 2020), yang menyatakan bahwa kinerja seorang guru dapat ditingkatkan kinerjanya dan kreatifitasnya dengan kegiatan lesson study.

Bila mencermati realita yang ada di sekitar kita, masih adanya guru kelas yang masih belum mempunyai kompetensi professional. Indikasi ini berdasarkan masih banyaknya sekolah pada tingkatan dasar baik Sekolah Dasar maupun Madrasah Ibtidaiyah yang rendah mutunya. Hal ini mengisyaratkan bahwa guru kelas yang profesional masih belum terealisasi secara merata di seluruh lembaga pendidikan dasar yang ada di Indonesia. Di samping itu juga, masih banyaknya permasalahan baru yang ditemukan berkaitan dengan kompetensi seorang guru kelas. Misalnya, banyaknya guru kelas yang masih bersifat administrative, sehingga kompetensi professional guru masih belum menjadi prioritas. Akibatnya para siswa kurang diperhatikan bahkan terabaikan yang pada akhirnya berpengaruh terhadap prestasi hasil pembelajaran tematik integratifnya.

Di sisi lain, kita juga menyaksikan minat baca siswa di Indonesia sangatlah rendah. Padahal minat baca siswa itu mempunyai pengaruh yang besar terhadap kebiasan membaca dan hasil pembelajaran tematik integratif. Menurut hasil penelitian PISA (Programme for International Student Assessment) menyatakan bahwa "Minat baca para siswa betul-betul jeblok yaitu para siswa menduduki urutan ke 75 dari 79 dari negara-negara yang masuk anggota Organization for Economic Co-operation and Development (OECD) di mana rata-rata siswa Indonesia hanya meraih skor 371 dari skor total 600, sedangkan rata-rata seluruh negara peserta mencapai 487" (Jumaroh, 2021). Rendahnya minat baca siswa ini diakibatkan di antaranya oleh menjamurnya jenis hiburan, game (permaianan) dan berbagai macam tayangan TV yang dapat mengalihkan perhatian siswa dari buku bacaan yang mendidik. Hiburan, permainan dan berbagai tayangan TV mengakibatkan waktu belajar siswa menjadi habis digunakan untuk menyaksikan hiburan, permainan dan berbagai tayangan TV tersebut.

Selain itu, juga ada faktor lainnya, seperti yang dikatakan Prof. Dr. Riris K. Toha Sarumpaet bahwa sekolah sebagai wadah untuk menumbuh kembangkan minat baca para siswanya sudah tidak memadai lagi. Hal ini disebab oleh kurikulum yang diterapkan. Kurikulum yang diterapkan disekolah sangat padat sehingga para siswa tidak mempunyai waktu luang untuk membaca (Shofaussamawati, 2014).

Penelitian atau artikel yang yang relevan dengan permasalahan ini sudah ada sebelumnya di antaranya adalah penelitian yang berjudul "Profesionalisme Guru Sekolah Dasar" (Sukmawati, 2016), "Pengaruh Profesionalisme Guru Dan Motivasi Kerja Terhadap Kinerja Guru Ekonomi SMA Se-Kota Malang” (T. A. Dewi, 2015), "Faktor Sosial Profesionalisme Guru" (Herlina, 2018), "Hubungan Minat Baca dengan Prestasi Belajar Kompetensi Bahasa Indonesia Siswa Kelas IV SD" (Maola \& Rida, Fironika Kusumadewi, 2019) dan "Hubungan Antara Minat Baca Dengan Prestasi Belajar Pada Mata Pelajaran Produktif di SMK" (Sabriyadi et al., 2015). Namun penelitian ini berbeda dengan penelitian atau artikel yang disebutkan di atas, karena 
mencoba secara mendalam dan spesifik akan mengkaji tentang bagaimana profesionalisme guru kelas dalam pembelajaran tematik integratif guna menerapkan kurikulum 2013. Sedangkan berkaitan dengan minat baca siswa di penelitian ini didekati dari sudut pandang psikologis. Hal ini keduanya kemudian akan dicari kontribusinya terhadap prestasi hasil pembelajaran tematik integratif yang telah dilakukan sebagai implementasi kurikulum 2013.

\section{METODE PENELITIAN}

Penelitian ini menggunakan jenis penelitian survei yang bersifat Ex Post Facto. Hal ini dikarenakan peneliti meliwati suatu peristiwa yang telah terjadi dan untuk menemukan dan menentukan beberapa factor atau beberapa sebab yang telah mendahuluinya guna menjelaskan suatu peristiwa yang diteliti dengan menurutnya ke belakang (Sugiono dalam Sholeh, 2014). Populasi penelitian ini adalah para siswa yang sedang menempuh pendidikan di Madrasah Ibtidaiyah Raden Fatah Pujon kabupaten Malang. Sedangkan teknik pengambilan sample mengikuti pendapatnya (Arikunto, 1983) bahwa, "apabila jumlah subyek kurang dari 100 orang lebih baik jumlah tersebut diambil semua, sehingga penelitiannya menjadi penelitian populasi, selanjutnya apabila jumlah subyek besar atau lebih dari 100 orang maka dapat diambil antara 10\%-15\% atau 20\%-25\% atau lebih". Berdasarkan pendapat di atas, maka sample pada penelitian ini sejumlah 22\% dari jumlah 300 populasi siswa, sedangkan sampel guru diambil semuanya sebanyak 19 orang. Sample diambil dengan menggunakan metode random sampling dengan cara undian, sehingga sampel yang diperolehnya adalah 66 siswa. Adapun indikator instrumenya profesionalisme guru kelas ini berdasarkan Permendiknas Nomor 16 tahun 2007 dan model teorinya Gagne (Syah, 1999) adalah sebagai berikut :

Tabel 1. Indikator Instrument Profesionalisme Guru Kelas

\begin{tabular}{|c|l|}
\hline \multicolumn{1}{|c|}{ Variabel } & \multicolumn{1}{c|}{ Indikator } \\
\hline $\begin{array}{c}\text { Profesionalisme } \\
\text { Guru Kelas }\end{array}$ & 1. Kemampuan merencanakan program \\
\hline & 2. Menguasai bahan pelajaran \\
\hline & 3. Melaksanakan /mengelola proses belajar-mengajar \\
\hline & 4. Menilai kemajuan proses belajar-mengajar \\
\hline
\end{tabular}

Sedangkan indikator dari instrumen minat baca siswa. adalah sebagai berikut :

Tabel 2. Indikator Instrument Minat Baca Siswa

\begin{tabular}{|c|l|}
\hline Variabel & \multicolumn{1}{|c|}{ Indikator } \\
\hline Minat Baca siswa & 1. Aspek respon \\
\hline & 2. Aspek perhatian \\
\hline & 3. Aspek perasaan \\
\hline
\end{tabular}

Adapun teknik analisis datanya menggunakan teknik analisis statistic inferensial dengan menggunakan analisis regresi ganda yang sebelumnya terlebih dahulu dilakukan uji prasyaratnya guna menguji hipotesis yang ada dalam penelitian ini. 
780 Kontribusi Profesionalisme Guru Kelas dan Minat Baca Siswa dalam Meningkatkan Prestasi Hasil

Pembelajaran Tematik Integratif-Ahmad Sholeh

DOI: https://doi.org/10.31004/edukatif.v3i3.425

\section{HASIL DAN PEMBAHASAN}

Berdasarkan hasil perhitungan analisis regresi ganda di peroleh koefisien determinan $\mathrm{R}^{2}$ sebesar 0,367 , $\mathrm{p}=0,026$. Ini berarti variable prestasi hasil belajar pembelajaran tematik integratif dipengaruhi oleh kopetensi profesioanal guru kelas dan minat baca siswa secara bersama-sama dengan kontribusi $36,7 \%$. Sedangkan selebihnya dipengaruhi oleh variable lain selain variable kopetensi profesioanl guru kelas dan minat baca siswa. Hasil perhitungan ini dapat dilihat pada table sebagai berikut :

Table 3. Kontribusi antara Variabel X1, X2 terhadap Y

\begin{tabular}{ccc}
\hline Variabel & $\mathrm{R}^{2}$ & $\mathrm{p}$ \\
\hline $\mathrm{X} 1, \mathrm{X} 2-\mathrm{Y}$ & 0,367 & 0,026 \\
\hline
\end{tabular}

Berdasarkan analisis di peroleh harga $\mathrm{F}=4,644$ dengan harga sebesar $\mathrm{p}=, 026$. Oleh karena nilai $\mathrm{p}<$ 0,05. Ini berarti Ha diterima dan Ho ditolak. Hal ini dikarenakan ada ketentuan penerimaan dan penolakan terjadi jika siqnifikansi dibawah atau sama dengan 0,05. Dengan demikian dapat disimpulkan bahwa antara kopetensi profesioanal guru kelas dan minat baca siswa secara bersama-sama memberikan kontribusi yang nyata terhadap prestasi hasil belajar pembelajaran tematik integratif. Hasil pengujian pengaruh ini dapat dilihat pada tabel sebagai berikut:

Tabel 4. Hasil Analisis Regresi Ganda dengan Variabel X1, X2 terhadap Y ANOVA(b)

\begin{tabular}{ccccc}
\hline Model & $\begin{array}{c}\text { Sum of } \\
\text { Squares }\end{array}$ & Mean Square & F & Sig. \\
\hline Regression & 116,952 & 58,476 & 4,644 &, $026(\mathrm{a})$ \\
\hline Residual & 201,469 & 12,592 & & \\
\hline Total & 318,421 & & & \\
\hline
\end{tabular}

a Predictors: (Constant), X1, X2

$b$ Dependent Variable: $\mathrm{Y}$

Hasil penelitian ini mempertegas bahwa bila guru kelas profesional maka guru akan mudah menjalankan tugasnya sehari-hari. Tugas pokok seorang guru kelas di sini ialah membantu para siswanya agar dapat beradaptasi dengan berbagai macam tantangan hidup dan desakan-desakan yang berkembang di dalam dirinya. Pemberdayaan para siswa itu meliputi berbagai aspek kepribadian dalam dirinya di antaranya pada aspek intelektual, sosial, emosional, maupun keterampilan. Tugas mulia ini sebenarnya sangat mulia, karena seorang guru kelas bukan saja harus mampu mempersiapkan generasi-generasi yang dapat memasuki abad pengetahuan, tetapi juga harus dapat mampu mempersiapkan dirinya sendiri agar bisa tetap eksis, baik secara individu, sosial maupun secara professional.

Guru kelas yang profesional haruslah mempunyai kapasitas bidang keilmuan yang luas dan tinggi. Oleh karena itu seorang guru kelas sangat perlu dibekali berbagai prasyarat baik yang berkaitan dengan syarat akademis maupun syarat non akademis. Berkaitan dengan ini banyak para pakar pendidikan berpendapat yang pada intinya bahwa mengarah kepada terealisasinya seorang sosok guru kelas yang ideal dan mempunyai kapasitas dan kualitas keilmuan yang memadahi. Misalnya saja Uzer Usman yang mengutip pernyataan Moh. Ali, yang mengatakan bahwa ada beberapa prasyarat yang harus dimiliki oleh seorang guru di antaranya: Pertama, menuntut adanya ketrampilan yang berdasarkan konsep dan teori ilmu pengetahuan yang mendalam Kedua, menekankan pada suatu keahlian dalam bidang tertentu sesuai dengan bidang profesinya. Ketiga, menntut adanya tingkat pendidikan keguruan yang memadahi. Keempat adanya kepekaan terhadap dampak kemasyarakatan dari pekerjaan yang memadahi, dan Kelima, memungkinkan perkembangan sejalan dengan dinamika kehidupan (Muchlisin Riadi, 2015). 
Sebenarnya seorang guru kelas berdasarkan Undang-Undang Guru dan Dosen itu mempunyai kwajiban yang lebih komprehensif dan holistic dalam rangka menjalankan keprofesionalannya. Dalam Undang-Undang Guru dan Dosen tahun 2005 itu dinyatakan bahwa seorang guru harus dapat; "(1) merencanakan pembelajaran, melaksanakan proses pembelajaran yang bermutu, serta menilai dan mengevaluasi hasil pembelajaran, (2) meningkatkan dan mengembangkan kualifikasi akademik dan kompetensi secara berkelanjutan sejalan dengan perkembangan ilmu pengetahuan teknologi dan seni, (3) bertindak objektif dan tidak diskriminatif atas dasar pertimbangan jenis kelamin, agama, suku, ras, dan kondisi fisik tertentu, atau latar belakang keluarga, dan status ekonomi peserta didik dalam pembelajaran, (4) menjunjung tinggi peraturan perundang-undangan, hukum, dan kode etik guru, serta nilai-nilai agama dan etika, dan (5) memelihara dan memupuk persatuan dan kesatuan bangsa".

Berdasarkan pengamatan peneliti waktu ke madrasah untuk mencari data ditemukan masih adanya sebagian guru kelas menggunakan strategi yang monoton dan masih mengggunakan pembelajaran langsung sehingga mengakibatkan para siswa merasa jenuh. Padahal seorang guru kelas diharapkan mampu mendorong dan memutivasi minat baca siswa. Minat baca siswa akan tumbuh dengan baik bila seorang guru mampu menghadirkan bacaan yang sesuai dengan kebutuhan para siswa. Bila minat baca para siswa baik maka akan berusaha membaca buku bacaan yang variatif. Pada akhirnya menurut (Budianti \& Damayanti, 2017), kegemaran membaca akan ada dalam diri siswa dan membaca adalah suatu kebutuhan dalam kehidupan siswa. Sehingga terbentuklah perilaku "tiada hari tanpa membaca".

Jika seorang siswa mempunyai minat baca dalam dirinya sangat kuat, maka akan timbul kesadaran akan membacanya. Selanjutnya bila kebiasaan membaca ini tertanam dalam diri para siswa maka rutinitas mambaca akan menjadi kebiasaan yang selalu dijalankan tanpa siswa merasa terbebani (Muslimin, 2018). Untuk membantu siswa dalam kegiatan literasi baca ini, guru kelas hendaknya memberi bekal strategi membaca kepada siswa agar mampu memahami dengan tepat bacaannya dengan mendalam. Ahuja dan Ahuja (Samsiyah, 2020) menyatakan bahwa ada dua strategi membaca yang dapat dilatihkan kepada para siswa, yaitu; pertama, mengurangi kecepatan membaca, jika; 1 . Ditemukannya kata, konsep atau materi yang sukar dipahami akan arti atau maknanya, 2. Sulitnya struktur kalimat atau paragraph, 3. Ditemukannya materi yang berupa diagram yang menuntut akan kehati-hatian Ketika ingin memahaminya, 4. Adanya unsur hayalan dalam tulisan artistic. Kedua, meningkatkan kecepatan membaca, jika: 1. Materinya sederhana dan Siswa hanya membutuhkan sedikit informasi yang baru. 2. Tidak dibutuhkannya contoh atau penjelasan yang detail dan elaborasi penjelasan. 3. Dinyatakannya ide-ide sebelumnya. 4. Tidak ditemukannya materi yang mengandung ide dan fakta yang penting.

Memang meningkatkan minat baca para siswa pada usia sekolah dasar tidaklah mudah dilakukan oleh guru kelas. Namun hal ini bisa dilakukan dengan bekerja sama dengan para orang tua siswa. Orang tua hendaklah menjadi suri tauladan yang baik di depan anaknya di rumah, misalnya dengan memfasilitasi anakanaknya agar tumbuh minat bacanya. Orang tua bisa memberi waktu luang dan perhatiannya supaya anak mereka bisa belajar dengan suasana lingkungan kondusif. Orang tua harus mampu juga memahami bacaan yang dibaca siswa guna membantu meningkatkan literasi baca siswa. Bahkan menurut (Fikriyah et al. 2020) berdasarkan penelitiannya menyatakan bahwa peran orang tua terhadap peningkatan literasi baca anak bisa diilakukan dengan pembiasaan, modelling, dan reward dan punishment.

Hasil perhitungan data menunjukkan bahwa minat baca siswa yang berada pada kategori tinggi berjumlah 39 (59\%), berkategori sedang berjumlah 10 (15\%), yang berada pada kategori rendah berjumlah 13 (20\%) dan yang berada dalam kategori sangat rendah $4(6 \%)$. Walau hasil perhitungan data menunjukkan minat baca yang berkategori tinggi sebesar 59\%, bila kita melihat rentan usia anak Sekolah Dasar berdasarnya pendapat Piaget dalam kategori pada tingkatan operasional kongkrit, maka baik guru kelas maupun orang tua harus lagi mengupayakan untuk menyediakan bacaan-bacaan yang sesuai dengan tingkatan usia ini, agar siswa lebih termotivasi lagi minat bacanya yang pada akhirnya berpengetahuan yang luas. 
782 Kontribusi Profesionalisme Guru Kelas dan Minat Baca Siswa dalam Meningkatkan Prestasi Hasil Pembelajaran Tematik Integratif-Ahmad Sholeh

DOI: https://doi.org/10.31004/edukatif.v3i3.425

Berdasarkan analisis di atas, dapatlah disimpulkan bahwa peran guru yang professional berpengaruh besar terhadap keberhasilan para siswa dalam menempuh pendidikannya. Di sinilah guru harus juga beriman dan berkarakter dan selalu mengamalkan ilmu pengetahuannya sehingga menjadi teladan yang baik di depan siswanya serta bertanggung jawab. Pengembangan guru kelas haruslah diarahkan pada dimensi pengusasaan ilmu, kompetensi yang perlu dikuasai oleh guru kelas, ketrampilan maupun pada dimensi perilakunya. (Desilawati \& Amrizal, 2014) menyatakan bahwa kebaradaan guru professional di lembaga-lembaga pendidikan di Indonesia merupakan prasyarat wajib yang harus dipenuhi untuk meningkatkan kualitas pendidikan agar supaya bisa bersaing dengan negara-negara berkembang dan maju lainnya. Semua bangsa yang ada di dunia ini melalui pengembangan kebijakannya itu selalu mendorong terbentunya guru yang berkualitas dan kompeten.

Guru kelas di dalam proses pembelajaran tugas pokoknya adalah mengarahkan para siswanya untuk dapat bisa mencapai tujuan pembelajaran. Guru kelas harus mampu menyampaikan isi bahan pembelajaran. Para guru kelas dituntut bisa menjelaskan materi pembelajaran tematik dengan berbagai prespektif disiplin ilmu. Oleh karena itu para guru kelas harus selalu membaca dan mengikuti perkembangan ilmu pengetahuan. Guru kelas juga harus dapat menciptakan suasana pembelajaran yang dapat memutivasi para siswa untuk bisa belajar dengan mau membaca. Guru kelas haruslah dapat menguasai berbagai macam strategi dan metode mengajar dengan baik dengan penguasaan multi media pembelajaran. Selanjutnya guru kelas harus dapat berinovasi dalam proses pembelajaran. Setelah itu, pada akhir pembelajaran guru kelas juga dituntut untuk mampu melaksanakan evaluasi yang tepat agar para siswa bersungguh-sungguh dalam pembelajaran tematik integratif. Dengan demikian out put yang dihasilkan akan lebih kompeten dan maksimal atau dengan kata lain prestasi yang akan dihasilkan akan lebih baik.

Di sisi lain, seorang guru kelas dituntut untuk dapat meningkatkan lemahnya minat baca siswa. Hal inilah yang menyebabkan nilai siswa kurang memuaskan bahkan terpuruk dibawah KKM, apabila para guru kelas kurang tepat menerapkan metode pembelajaran. Oleh karena itu salah cara yang dapat meningkatkan minat baca siswa adalah dengan cara membudayakan kebiasaan membaca. Dengan cara ini dalam diri siswa akan tumbuh dan berkembangnya minat membaca. Dengan demikian proses pembelajaran tematik integratif dapat berjalan dengan baik. Ketika minat baca para siswa tinggi dalam proses belajar mengajar maka akan dapat memperbaiki proses pembelajaran tersebut semakin baik. Begitupun sebaliknya semakin rendah minat baca siswa maka kualitas PBM akan semakin menurun dan akan mempengaruhi hasil prestasi belajar siswa.

Hasil penelitian ini sesuai dengan hasil penelitiannya (Permatasari \& Sobandi, 2019) menyatakan bahwa prefesionalisme guru itu mempunyai pengaruh yang signifikan terhadap prestasi belajar siswa dan (R. Dewi \& Khotimah, 2020) yang menyatakan profesionalisme guru berpengaruh pada mutu pendidikan. Di samping itu juga menegaskan penelitiannya (Sari et al., 2020) dan (Putri et al., 2017) yang mengatakan bahwa minat baca juga berpengaruh terhadap prestasi belajar siswa. Namun pada penelitian kedua paling awal di atas merupakan penelitian yang dilakukan pada tingkat Sekolah Menengah Kejuruan (SMK) dan memposisikan objek penelitian pada SDN 01 Ciporang dengan memfokuskan pada mutu pendidikan sebagai variabel dependent. Sedangkan pada penelitian kedua memfokuskan pada prestasi bahasa Indonesia dan menjadikan objeknya pada Sekolah Menengah Atas (SMA).

Dengan demikian penelitian ini berbeda dengan penelitian-penelitian tersebut di atas, karena memfokuskan pada hasil belajar pembelajaran tematik integratif yang mempunyai pola pendekatan pembelajaran scientific dan tematik integratif dengan mengambil objek di Madrasah Ibtidaiyah yang mempunyai ke khasan kurikulum yaitu memadukan antara kurikulum keislaman dan kurikulum tematik 2013. Walaupun adanya keterbatasan objek penelitiannya yang hanya di satu lembaga pendidikan Islam yang sedang berkembang, namun dengan ditemukan adanya kontribusi yang signifikan pada penelitian ini, diharapkan dapat dijadikan sebagai dasar penyusunan program perbaikan di bidang pendidikan terutama dalam mengembangkan proses pembelajaran tematik integratif di Madrasah Ibtidaiyah. 


\section{KESIMPULAN}

Dari uraian yang ada dapat ditarik kesimpulan bahwa prestasi hasil belajar pembelajaran tematik integratif dipengaruhi oleh kopetensi profesioanal guru kelas dan minat baca siswa secara bersama-sama dengan kontribusi $36,7 \%$. Hal ini berdasarkan hasil perhitungan analisis regresi ganda di peroleh koefisien determinan $\mathrm{R}^{2}$ sebesar $0,367, \mathrm{p}=0,026$. Ini berarti prestasi hasil belajar pembelajaran tematik integratif selebihnya dipengaruhi oleh variable lainnya. Dengan mempertimbangkan hasil penelitian ini maka perbaikan dalam rangka meningkatkan meningkatkan kualitas mutu pembelajaran tematik integratif di Madrasah Ibtidaiyah harus terus dilakukan. Perbaikan-perbaikan itu meliputi sebagai berikut : Pertama, para pengajar atau guru kelas haruslah membangun dan mengasah lagi kopetensi profesionalnya dalam rangka mengembangkan proses belajar mengajar yang lebih baik sehingga prestasi siswa dalam pembelajaran terpadu lebih optimal. Kedua, minat baca siswa yang ada di MI harus lagi dikembangkan secara maksimal agar nantinya akan menjadi orang yang berhasil di kehidupannya nanti dan mampu berkompetitif di era sekarang ini.

\section{DAFTAR PUSTAKA}

Arikunto, S. (1983). Prosedur Penelitian. Bumi Aksara.

Budianti, Y., \& Damayanti, N. (2017). Pengaruh Metode KWL (Know Want to Learn) terhadap Keterampilan dan Minat Membaca Siswa. Indonesian Journal of Primary Education, 1(2), 13. https://doi.org/10.17509/ijpe.v1i2.9311

Desilawati, \& Amrizal. (2014). Guru Profesional di Era Global. Pengabdian Kepada Masyarakat, 20(77), 14. https://jurnal.unimed.ac.id/2012/index.php/jpkm/article/view/3415

Dewi, R., \& Khotimah, S. H. (2020). Pengaruh Profesionalisme Dan Disiplin Kerja Guru. ELEMENTARY Islamic Teacher Journal, 8(2), 279-294.

Dewi, T. A. (2015). Pengaruh Profesionalisme Guru dan Motivasi Kerja Guru Ekonomi. Jurnal Pendidikan Ekonomi, 3(1), 24-35. https://media.neliti.com/media/publications/162610-ID-pengaruhprofesionalisme-guru-dan-motiva.pdf

Fikriyah, F., Rohaeti, T., \& Solihati, A. (2020). Peran Orang Tua dalam Meningkatkan Literasi Membaca Peserta Didik Sekolah Dasar. DWIJA CENDEKIA: Jurnal Riset Pedagogik, 4(1), 94. https://doi.org/10.20961/jdc.v4i1.43937

Hayu, W. R. R., Permanasari, A., Sumarna, O., \& Hendayana, S. (2020). PENGEMBANGAN PROFESIONALISME GURU IPA SMP BPI BANDUNG. JURNAL SOSIAL HUMANIORA, 11(1). https://doi.org/10.30997/jsh.v11i1.2182

Herlina, H. (2018). Faktor Sosial Profesionalisme Guru. Jurnal Ilmiah Iqra', 12(2), 125. https://doi.org/10.30984/jii.v12i2.898

Jumaroh, \& A. (2021). Minat dan Kebiasaan Baca Literatur Bahasa Inggris Mahasiswa Kesehatan. EDUKATIF: JURNAL ILMU PENDIDIKAN, Volume $3 \quad N, \quad 529-538$. https://doi.org/https://doi.org/10.31004/edukatif.v3i2.336

Maola, M., \& Rida, Fironika Kusumadewi, \& A. P. C. (2019). Hubungan Minat Baca Dengan Prestasi Belajar Kompetensi Bahasa Indonesia Siswa Kelas IV SD. KONFERENSI ILMIAH MAHASISWA UNISSULA (KIMU) 2, 1391-1397.

Muchlisin Riadi. (2015). Profesionalisme dan Kompetensi Guru. https://www.kajianpustaka.com/2015/11/profesionalisme-dan-kompetensi-guru.html 
784 Kontribusi Profesionalisme Guru Kelas dan Minat Baca Siswa dalam Meningkatkan Prestasi Hasil Pembelajaran Tematik Integratif-Ahmad Sholeh

DOI: https://doi.org/10.31004/edukatif.v3i3.425

Muslimin. (2018). Penumbuhan Budaya Literasi Melalui Peningkatan Minat Baca Masyarakat desa. Cakrawala Pendidikan, 37(1), 107-118.

Permatasari, I., \& Sobandi, A. (2019). Profesionalisme Guru Sebagai Determinan Terhadap Prestasi Belajar Siswa. Jurnal Pendidikan Manajemen Perkantoran, 4(2), 182. https://doi.org/10.17509/jpm.v4i2.18013

Putri, K., Djaja, S., \& Suyadi, B. (2017). The Influence of Learning Interest and Emotional Intelligence towards Learning Achievement Grade XI Senior High School 1 Prajekan Regency Bondowoso School Year 2016/2017. Jurnal Pendidikan Ekonomi, 11(2017), 67-74.

Rosmawati, R., Ahyani, N., \& Missriani, M. (2020). Pengaruh Disiplin dan Profesionalisme Guru terhadap Kinerja Guru. Journal of Education Research, 1(3). https://doi.org/10.37985/jer.v1i3.22

Sabriyadi, S., Sumarna, N., \& Permana, T. (2015). Hubungan Antara Minat Baca Dengan Prestasi Belajar Pada Mata Pelajaran Produktif Di Smk. Journal of Mechanical Engineering Education, 2(1), 124. https://doi.org/10.17509/jmee.v2i1.1162

Samsiyah, N. (2020). Budaya Lokal Untuk Meningkatkan Literasi Baca Siswa Sekolah Dasar. Seminar Nasional Pendidikan 208-217. http://eproceedings.umpwr.ac.id/index.php/semnaspgsd/article/view/1385

Sari, M. Z., Gunawan, A., Fitriyani, Y., \& Hilaliyah, N. (2020). Pengaruh Minat Baca Siswa Terhadap Hasil Belajar pada Pelajaran Bahasa Indonesia di SD Negeri 1 Ciporang. DWIJA CENDEKIA: Jurnal Riset Pedagogik, 4(2), 197. https://doi.org/10.20961/jdc.v4i2.42137

Shofaussamawati. (2014). Menumbuhkan minat baca dengan pengenalan perpustakaan pada anak sejak dini. Libraria, 2(1), 46-59.

Sholeh, A. (2014). Pemahaman Konsep Tasamuh (Toleransi) Siswa Dalam Ajaran Islam. J-PAI: Jurnal Pendidikan Agama Islam, 1(1), 101-132. https://doi.org/10.18860/jpai.v1i1.3362

Sukmawati, S. (2016). Profesionalisme Guru Sekolah Dasar. Jurnal Visi Ilmu Pendidikan, 7(2). https://doi.org/10.26418/jvip.v7i2.17055

Syah, M. (1999). Psikologi Belajar (ke-2). Logos Wacana Ilmu. 